\title{
THE HISTORY OF DEPARTMENT OF UROLOGY AT MEDICAL FACULTY OF CHARLES UNIVERSITY IN HRADEC KRÁLOVÉ
}

\author{
Petr Morávek \\ Department of Urology, Charles Univesity, Faculty of Medicine, Hradec Králové; \\ (Head: doc. MUDr. P. Morávek, CSc.)
}

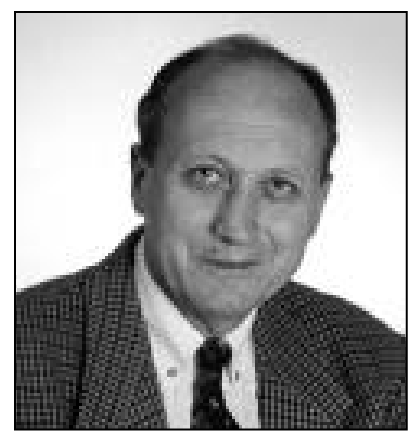

Assoc. Prof. P. Morávek (1942)

\section{Foundations of the Department of Urology}

The history of the Department of Urology in Hradec Králové is unequivocally connected with the name of Academician Jan Bedrna. The roots of its history can be traced to Bedrna's appointment as the Head of Surgical Department in Hradec Králové. Associate Professor Bedrna (pupil of Professor Petřivalský) had gradually grewn up to become an outstanding, rather versatile surgeon. From the very beginning of his medical career he was interested mainly in urology, especially in children's urology, as he expressed in his book „The Child's Urology“. This book hasn't lost any of its value even after 45 years. Being a forethoughtful, progressive surgeon, Bedrna was wise enough to foresee the necessity of segregating the individual specialized surgical fields, and that is also why he established an independent urological ward within the surgical department of the hospital. This act represented laying the foundations of the independent urological department.

Bedrna was not only the pioneer of the idea of independent urology in Hradec Králové, but also propagator of the separation of urology as a medical branch, when being a member of the Czechoslovak Surgical Association in the early fifties. Following a lot of stern discussions a committee for urological problems was constituted in 1953 and two years later an independent section was founded with Professor Neuwirt as Chairman and Academician Bedrna as Deputy Chairman.

Shortly after World War II, in November 1945, the Faculty of Medicine was established in Hradec Králové as a branch of Charles' University in Prague.

An important point in the Faculty development was the year 1951 when it became a Military Medical Academy. While being controlled by the Army some new lecturers, such as Šváb, M.D (1951-1992), Stefan, M.D. (1952-1960, later Head of the Paediatric Surgery Department), Navrátil,
M.D. (1954-1990), and Jeřábek, M.D. (1955-1992) were acquired for the Academy. When mentioning all these famous names, last but not least, I would like to remind the external postgraduate Zvara, M.D. (1953-1955), whose supervisor was Academician Bedrna himself. Professor Zvara later became Head of the Department of Urology in Bratislava.

The next step, significantly influencing the establishment of an independent department of urology, was represented by transformation of Military Academy of Medicine back into a civilian Faculty in the year 1958. Other highly educated lecturers started working there. In 1959 Konečný came to the department (later Head of the Urological Department in Haviŕov) and in the year 1961 Pokorný came.

\section{Establishment of the first University Department of Urology in Bohemia and the initial period of its activities}

The fast development of urology as a scientific branch, its high quality within the Surgical Department in Hradec Králové and, of course, the heritage of Professor Bedrna were decisive. On March the 1st, 1962, according to the decision of the Minister of Health Service Plojhar, Th.D., with the agreement of the Minister of Education, the first University Department of Urology in Bohemia was founded.

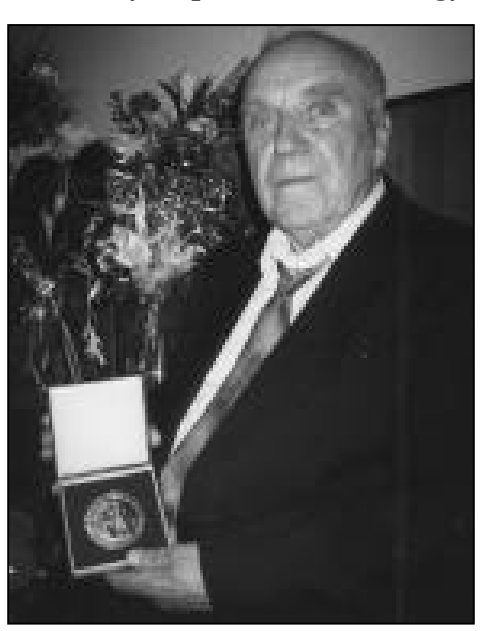

Prof. J. Šváb, M.D., Ph.D. The first Head of the Department of Urology Prof. Šváb, M.D. became the Head, Navrátil, Jeřábek, Konečný and Pokorný formed the staff.

In the year 1967 Konečný left the Department and new people, seriously interested in urology, came: Baše M., M.D. (1968-1973), Baše J., M.D. (1969-till now), Morávek, M.D. (1971-till now), Navrátilová, M.D. (1974-till now), Navrátil Jr., M.D. (1976-till now), Hiblbauer, M.D. (1976-1995) 
and Zita, M.D. (1984-1995). At that time there were 31 hospital beds there. Associate Professor Pokorný, the senior lecturer, leaved in 1975 and became Head of the Urological Department in Plzeň.

When in the year 1983 Professor Šváb retired, his longtime colleague, Professor Navrátil, who also acted as the Dean of the Medical Faculty, became Head of the Department of Urology.

\section{The following period of Department existence in the new building}

The next stage began when the Department moved into a new Surgical pavilion in 1985. It was named after Academician Bedrna. Nowadays, our Department has 69 hospital beds (55 for adults, 14 for children). The Department of Paediatric Urology within the Department of Urology was established in 1986 and J. Baše became the leading surgeon. New doctors have come to the Department since that time: Novák, M.D. (1987-till now), Janoušková, M.D. (1987-till now), Rýdel, M.D. (1987-till now), Kutílek, M.D. (1987-till now), Šístek, M.D. (19901995) and Louda, M.D. (1992-till now).

The reason for such a staff expansion was a necessity to amplify the team because of the increasing number of beds and also as the out-patient care and complement were extended. Nowadays, at the Department there are special Xray and endoscopical rooms, operating and ESWL rooms. The Department has been fully equipped with modern devices and appliances, the diagnostics and treatment are generally considered to be of a high quality and comparable with the best Czech and even European departments.

\section{Department priorities in the field of medical care, pre- and postgradual tuition and publications activities}

Moreover, there are some priorities in medical care and prevention of the Department of Urology in Hradec Králové, springing not only from recent days, but also from the previous times. In the year 1953 the first suprapubic transvesical prostatectomy with primary closing of the bladder in the Czech Republic was carried out in Hradec Králové. In 1956 the first ileocystoplastics in our country and in 1961 the first kidney transplantation in Middle Europe were performed. Our Department was among the first ones in this country where antireflux operations, operations for bladder exstrophy, resection pyeloplastics, kidney resections, nefrectomy with resection of the lower caval vein because of the tumorous thrombotic process and retroperitoneal and pelvic lymphadenectomy in the presence of prostate and testicle carcinoma have been performed. Lately, radical prostatevesiculectomy and orthotopic continuous derivation of urine with creating an ileal bladder after cystectomy were carried out. Also the Transplantation Centre has developed success- fully. It was established in the year 1978 and since 1988 it has been working under heading of Navrátil, Jr., M.D. Even the modern treatment of urolithiasis (ESWL) is prosperous, too.

Parallelly to medical care, the Department is being fully involved in the pregradual tuition of students, postgradual lessons for doctors and scientific research, as well.

Three doctors, members of our Department, have become Professors (Šváb, Navrátil, Stefan), three Associate Professors (Pokorný, Morávek, Baše) and 9 doctors have reached the scientific titles Ph.D.

The scientific papers published by the Department workers have dealt with kidney resection, surgery of suprarenal glands, using the small intestine for replacing the bladder (Šváb), kidney cancer surgery, tumorous thrombotic process in the lower caval vein (Navrátil, Morávek, Baše J., Navrátil Jr.), treatment of testicle carcinoma (Baše), diagnostics and treatment of prostate cancer (Morávek), etiology of bladder cancer (Pokorný), transplantology and endoprothetic aids in urology (Navrátil Jr.), and surgery of serious inborn defects - exstrophy, epispady, etc. (Stefan).

\section{The next period of Department activities after the change of the social system}

The last stage of the life of our Department is being connected with a change of the social system in the year 1989 . Prof. Navrátil, M.D. has retired, and after a short period of substituting, the senior lecturer Baše, M.D. took the office of the Department Head. Novák, M.D. became Head of the Department of Paediatric Urology. He had certain experience in paediatric urology and, moreover, which was very important, indeed, the previously retired Professor Stefan, M.D. has become his colleague and teacher. Paediatric Urology had always been Stefan's hobby and his decision to devote some time to the tuitioning and practising it again was positively accepted by hospital authorities. Prof. Šváb,

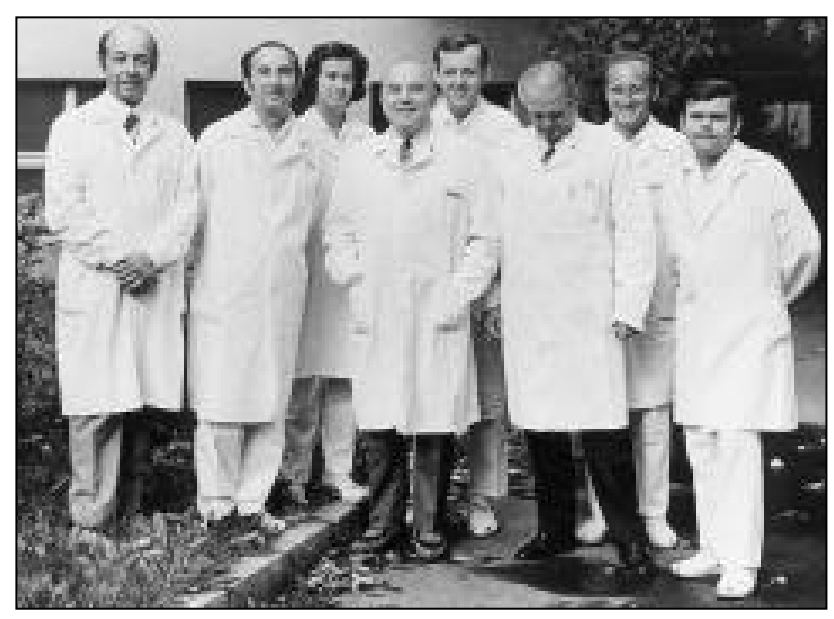

Medical staff on the Department of Urology in the year 1975. Navrátilová - Baše - Morávek

Pokorný - Jeř́bek - Šváb - Navrátil - Hofman 
who had been working as a consultant till the year 1992, has left the Department for his native town Bardějov, where in 1996 he celebrated his 80th birthday anniversary. I am sorry to state that Jeřábek, M.D. who had been working as a retired doctor at the out-patient departments in Hořice and Nová Paka, suddenly died in 1996. Hiblbauer, M.D. and Zita, M.D. started their private practices in 1995. They were gradually replaced by new doctors: Veselský, M.D. and Prošvic, M.D. in 1994, Brodák, M.D. and Pacovský, M.D. in 1996. In Autumn 1995 the Associate Professor Baše left his post of the Head of the Department because of serious health reasons.

In 1996, as a result of competition proceedings, the Associate Professor P. Morávek, the senior lecturer of the Department, was appointed as the Head of Department of Urology in Hradec Králové.

Contemporary activities should not be evaluated prematurely. But the credits and aims of the present representatives are clear: not only to maintain the good name of the Department and its good position among other Departments of Urology in the Czech Republic (having been achieved mainly by their teachers), but also to go ahead in prosperity of the Department itself. Development of scientific research and teaching activities of the
Department are being to be supported, as well. Nowadays, there is also an extra task concerning the economical prosperity of the Department. Purposive studies, postgradual sharing of knowledge, endeavour to gain experience by taking part in important sessions, congresses and trainings, both at home and abroad, represent, according to my opinion, the best means how to fulfil our goals and dreams.

Personally, I would further underline and stress the good working athmosphere based on fair and correct relationship between the colleagues. I do believe all these aims could be really reached.

I would like to express my gratitude to my first teacher of urology, to Prof. Šváb, M.D., Ph.D, who also provided me with the historical data. It was him who stood at the birth of the Department and whose efforts were remarkable.

Doc. MUDr. Petr Morávek, CSc., Department of Urology, Charles University, Faculty of Medicine, 50005 Hradec Králové, Czech Republic. 